\title{
Disseminated Tumor Cells in Bone Marrow and Circulating Tumor Cells in Blood of Breast Cancer Patients: Current State of Detection and Characterization
}

\author{
Sabine Riethdorf Klaus Pantel \\ Institute of Tumor Biology, University Medical Center Hamburg-Eppendorf, Hamburg, Germany
}

\author{
Key Words \\ Disseminated tumor cells $\cdot$ Bone marrow $\cdot$ Circulating tumor \\ cells $\cdot$ Blood $\cdot$ Breast cancer
}

\begin{abstract}
Despite the progress resulting from early detection and improved adjuvant therapy, the prognosis of breast cancer patients is still limited by the occurrence of distant metastases largely due to clinically occult micrometastases that remain undetected at primary diagnosis even by high-resolution imaging approaches. Recent research efforts have concentrated on the identification of additional parameters allowing individual risk assessment and stratification of patients for targeted therapies, since traditional prognostic factors are not sufficient to predict metastatic relapse and treatment decisions are still mainly based on statistical risk parameters. Highly sensitive and specific immunocytochemical and molecular assays now enable the detection and characterization of disseminated and circulating tumor cells (DTCs and CTCs, respectively) at the single cell level in bone marrow (BM) and peripheral blood, providing insights into the first crucial steps of the metastatic cascade. However, because of the still high variability of results in DTC/CTC detection, the necessity of standardized approaches will be discussed. A large number of studies showed that the presence of DTCs in BM has prognostic impact for primary breast cancer patients. DTCs are likely to escape from chemotherapy by
\end{abstract}

maintaining a dormant nonproliferating state. There is also evidence for a stem cell-like phenotype of DTCs, probably contributing to the opportunity to escape from dormancy control and to start expansion to manifest metastases. Blood would also be an ideal source for the detection and monitoring of CTCs because of an easy noninvasive sampling procedure enabling repeated analyses. While prognostic significance of CTCs could be reliably demonstrated for metastatic breast cancer, studies to analyze the impact of CTCs in primary breast cancer patients and the potential to replace or supplement BM analysis are still ongoing. Furthermore, molecular characterization of CTCs might contribute to improving targeted and more individualized cancer therapies.

Copyright @ 2008 S. Karger AG, Basel

\section{Introduction}

The occurrence of distant metastases is the main cause of death for breast cancer patients. However, crucial factors forcing cancer cells to move and grow outside of the primary organ are still not well understood [1]. An association of breast cancer and bone metastasis was already described in 1889 with the publication of Steven Paget's theory of seed and soil [2]. Breast cancer-related metastasis in bone marrow (BM) was also suggested by Rohr and Hegglin [3], who identified metastatic cells in BM biopsies by hematoxylin and eosin staining. When Schreiber

\section{KARGER \\ Fax +4161306 1234 \\ E-Mail karger@karger.ch}

www.karger.com
(C) 2008 S. Karger AG, Basel

1015-2008/08/0752-0140\$24.50/0

Accessible online at:

www.karger.com/pat
Prof. Dr. Klaus Pantel

Institute of Tumor Biology, University Medical Center Hamburg-Eppendorf Martinistrasse 52

DE-20246 Hamburg (Germany)

Tel. +494042803 3503, Fax +49 4042803 5379, E-Mail pantel@uke.uni-hamburg.de 
et al. [4] described the first single disseminated tumor cells in BM smears in nonmetastatic breast cancer patients, only a few publications dealt with micrometastasis [5]. Moreover, morphological criteria were not sufficient to undoubtfully distinguish single epithelial tumor cells from BM cells, especially because of the wide variety of morphologically uneven hematopoietic and mesenchymal stem as well as progenitor cells [6].

Important progress in the field of $\mathrm{BM}$ micrometastasis arose from the introduction of immunocytochemical staining procedures using antibodies against epithelialspecific markers (EMA, cytokeratins) that were not expressed on the surrounding BM cells [7]. Using these methods, it became more and more accepted during the last 2 decades that BM is a common homing and surviving organ not only for breast cancer cells but also for cancer cells from other organs $[8,9]$. These cells are likely to escape from the host immune system in a dormant state until internal and/or external signals might enable them to move and grow out to overt metastases at different organs [10-14].

In this review, we focus on modern sensitive and specific detection methods for disseminated and circulating tumor cells (DTCs and CTCs, respectively) as well as their clinical relevance. We will further concentrate on the question whether and when BM examination can be replaced and supplemented by blood analysis. Furthermore, we will present new data about the phenotypical and molecular characterization of DTCs and CTCs under particular consideration of cancer stem cell features and potential therapeutically relevant target molecules.

\section{Detection of DTCs in Bone Marrow}

Current models of breast cancer metastasis support the possibility of an early detachment of cells from primary tumors and the direct release of DTCs into blood and $\mathrm{BM}$, bypassing in some cases the lymphatic system $[1,13]$. DTCs are rare with only 10-20 cells among millions of BM cells. In order to increase the chance to detect DTCs in this organ, procedures had to be developed for their enrichment prior to detection and further characterization. To this end, different density gradient centrifugation methods such as Ficoll-based assays or the OncoQuick approach, as well as positive or negative immunomagnetic enrichment procedures and simple filtration methods separating tumor cells by their size, have been established $[13,15]$.

Disseminated and Circulating Tumor

Cells in Breast Cancer Patients
Today, in general, there are 2 different methods to screen BM aspirates for DTCs, namely cytologic/cytometric (antibody-based) and molecular approaches [13, 15, 16]. Among the cytologic methods that allow isolation and enumeration of individual cells, immunocytochemistry is the most widely used approach $[1,15]$. Because of the absence of tumor-specific target antigens, most frequently antibodies against various epithelium-specific antigens such as cytoskeleton-associated cytokeratins, surface adhesion molecules or growth factor receptors are applied for the detection of carcinoma cells [15-17]. The main advantage of cytologic methods is the opportunity to combine immunostaining with the morphology of the cells so that both cell size and shape as well as the nucleusplasma relation might be estimated and illegitimate expression of the protein of interest in BM cells can be excluded as far as possible. The detection of DTCs in BM is still not part of the routine tumor staging in the clinical practice, but emerging data anticipate a future role of DTC detection for risk stratification and therapeutic monitoring of breast cancer patients [18-20]. However, the detection rates of DTCs in BM from nonmetastatic breast cancer patients vary considerably [21, 22]. This might reflect the different sensitivity, but also specificity, of the numerous detection methods and marker genes/ proteins used thus far. The recently defined consensus concept for the detection of DTCs in BM, signifying enrichment of mononuclear cells from BM by Ficoll density gradient centrifugation and immunocytochemical detection of cytokeratin expression as standard procedure, should help overcome these problems and provide the basis for future multicentric clinical trials [23]. The authors recommend the pan-anti-cytokeratin antibodies A45-B/ B3 or AE1/AE3 against a wide spectrum of cytokeratins as standard application, thereby ensuring detection of DTCs also in cells that have downregulated the expression of individual cytokeratins in the course of epithelialmesenchymal transition [23]. Microscopic screening of large amounts of immunostained cytological preparations is accomplished by automatic microscopes using sophisticated imaging approaches. Criteria to evaluate morphology and staining results have also been defined to avoid false-positive and false-negative results [23-26]. Despite existing recommendations for standard operation procedures, however, there are still limitations to the standardization of immunocytochemical methods with respect to reproducibility of the staining procedure itself as well as microscopic interpretations. Therefore, both intraand interlaboratory evaluation of the methods is required to ensure reliability of the results [26].

Pathobiology 2008;75:140-148 141 
Besides immunocytochemical methods, very sensitive nucleic acid-based techniques now enable the detection of DTCs also at the single cell level. The main advantage of these methods is the nearly unlimited availability of primers for almost every gene of interest. Although numerous genetic alterations have been described in breast cancer cells, heterogeneity is enormous, so that at present no universally applicable DNA marker exists for the primary screening of a wide range of DTCs $[13,15]$.

Further efforts have been made to detect free circulating DNA or epigenetic alterations of circulating DNA such as methylation in BM and blood plasma, but the results are still preliminary $[27,28]$. Furthermore, it is unclear whether the amplified DNA derives from DTCs/ CTCs or is being shed from tumor or normal tissue [29].

Therefore, measurement of epithelium-specific or more organ-specific mRNA species such as cytokeratin 19 or mammaglobin mRNA by RT-PCR has been proven as promising approach to detect DTCs in BM samples [30-35]. Because of the absence of tumor-specific markers, the main drawback of using surrogate tissue-specific markers, however, are false-positive results due to illegitimate low-level transcription of epithelial or breast tissue-specific genes in normal cells $[29,36]$. Furthermore, heterogeneity in the expression of particular genes is not recognizable and the expression level of a gene of interest per cell cannot be estimated. Current analyses are mainly performed by quantitative real-time RT-PCR, ensuring the discrimination between different levels of expression. Moreover, multimarker real-time RT-PCRs have the potential to improve the method even in case of downregulation of the expression of a single gene [22, 37-39]. However, storage and sample preparation have to be performed under conditions avoiding RNA degradation, one of the major problems of RT-PCR approaches [35]. The application of multimarker assays might also compensate for low mRNA amounts due to the low number of tumor cells. There are several excellent reviews listing the marker genes currently used in RT-PCR approaches to detect DTCs in BM or CTCs in blood from breast cancer patients $[15,29,40]$.

The methods described above are not able to discriminate between viable and apoptotic DTCs. A new technique, designated EPISPOT (epithelial immunospot) offers the advantage of detecting viable tumor cells by their ability to secrete individual proteins. In a recently published study it could be demonstrated that BM samples from metastatic and nonmetastatic breast cancer patients contain viable tumor cells which secret Muc-1 and/or cytokeratin 19 in about 90 and 50\% of cases, respectively, whereas in controls from healthy women, cells secreting these proteins could not be detected [41].

\section{Clinical Relevance of DTCs in Bone Marrow}

A large number of studies have documented DTCs in BM from patients with most types of epithelial cancers [1, 8]. Within the last 15 years, several studies have demonstrated that detection of DTCs in BM of breast cancer patients is accompanied by a substantially worse prognosis [42-44]. In a pooled analysis evaluating the results from 9 different European centers, including a total of 4,703 patients, Braun et al. [19] have reported that approximately $30 \%$ of women with primary breast cancer have DTCs in BM, and in a multivariate analysis, the 10year follow-up of these patients revealed a significantly decreased overall survival, when compared to patients without DTCs. The presence of DTCs in BM was significantly associated with higher tumor stage, worse differentiation, lymph node metastasis and negativity in hormone receptor expression. Prognostic relevance was shown for all subgroups, even among those patients with small tumors and without lymph node metastasis. Although using different antibodies and detection methods, almost all investigators participating in this pooled analysis used anti-cytokeratin antibodies to screen for DTCs in the BM [19].

Moreover, Wiedswang et al. [45] and Janni et al. [20] demonstrated that the persistence of DTCs in BM from breast cancer patients after adjuvant therapy is predictive for a subsequent disease recurrence. However, only prospective clinical trials will show whether patients with persistent DTCs will benefit from a second-line adjuvant treatment, for example by bisphosphonates or antiangiogenetic therapeutics.

\section{Can Bone Marrow Examination for DTCs Be Replaced by Blood Analysis for CTCs?}

Aspiration of BM is invasive, time-consuming and in many cases painful or at least uncomfortable for the patients, precluding repeated samplings necessary for therapy-monitoring studies. Moreover, BM aspiration is more difficult to standardize with regard to the required volume and quality. Consequently, recent efforts have concentrated on the detection of CTCs in peripheral blood 
(PB) of cancer patients [29], but the clinical usage of CTCs has not yet been implemented for routine clinical practice. Furthermore, there are only a limited number of studies comparing $\mathrm{BM}$ and $\mathrm{PB}$ examinations performed at the same time points, and the clinical significance of CTCs in PB is less clear than that for DTCs in BM. In all studies published thus far, there was a higher frequency of BM-positive than blood-positive samples from the same patients [46-49], probably due to the fact that BM might provide conditions for homing and survival of DTCs, thus contributing to their accumulation in this compartment.

Although both Pierga et al. [46] as well as Muller et al. [47] reported about a significant number of patients with concordant results concerning BM and blood analysis, in the study of Pierga et al. [46] only the presence of DTCs in BM and not that of CTCs in blood had prognostic relevance for disease-free survival in nonmetastatic breast cancer patients. In a study reported by Wiedswang et al. [48] on 341 breast cancer patients with median 40 months of follow-up after surgery, both CTCs and DTCs were significantly associated with diseasefree survival; however, considering only node-negative patients, DTCs but not CTCs predicted differences in disease-free survival. Interestingly, the presence of both DTCs in BM and CTCs in blood in a subgroup of patients resulted in an especially poor prognosis [48]. While all studies mentioned above applied immunocytochemical methods, also real-time RT-PCR detection of DTCs in BM had superior prognostic significance in comparison with CTCs in patients with breast cancer [49]. In the study reported by Benoy et al. [49], cytokeratin 19 and mammaglobin mRNA levels were analyzed by quantitative RT-PCR.

Currently, the results obtained by comparative studies do not support a replacement of BM by blood analysis, but CTC detection might have supplementary value. There is an increasing number of studies demonstrating clinical relevance of CTCs in blood detected by real-time RT-PCR identifying either only cytokeratin 19 mRNA or multiple markers [15]. Recently, analyzing cytokeratin 19 mRNA by real-time RT-PCR, Xenidis et al. [50] reported about CTCs detected in 22\% of blood samples from 167 node-negative breast cancer patients as significantly associated with overall and disease-free survival. A correlation of the presence of CTCs in blood to the lymph node status was found in 2007 by Nakagawa et al. [51], who detected CTCs with the help of a multimarker real-time RTPCR in 39/90 (43\%) stage I-III breast cancer patients, but not in normal healthy volunteers.

Disseminated and Circulating Tumor

Cells in Breast Cancer Patients
The lack of standardization for CTC detection and high intra- and interlaboratory differences in the results have additionally complicated the introduction of PB testing into the clinical practice. Standardization and automation are also pivotal to ensure high-throughput analyses as a precondition for clinical application and multicenter studies. Important progress in this field arose from the development of an automated enrichment and immunocytochemical detection system for CTCs (CellSearch ${ }^{\mathrm{TM}}$ ) $[52,53]$. This system consists of an automated instrument for the enrichment of epithelial cells by ferrofluids coated with anti-EpCAM antibodies followed by immunostaining of captured cells with fluorescently labeled anti-cytokeratin and anti-CD45 antibodies (AutoPrep), and a semiautomated microscope for scanning and reading results (CellSpotter ${ }^{\circledR}$ Analyzer). Using this system, Cristofanilli et al. $[52,53]$ demonstrated in a prospective study that CTC detection provided significant prognostic information for patients with metastatic breast cancer. Additionally, Hayes et al. [54] demonstrated that CTCs at each follow-up time point during therapy of these metastatic breast cancer patients predict progression-free and overall survival. The CellSearch system has been cleared by the US Food and Drug Administration for routine clinical use in metastatic breast cancer patients. Validation data from 3 independent laboratories and high interinstrument accordance confirmed the reliability of this system for CTC measurements in PB from metastatic breast cancer patients. Furthermore, it was shown that samples can be shipped at room temperature and CTC counts are stable for at least $72 \mathrm{~h}$, which facilitates testing at central laboratories or remote sites requiring transportation [55].

There are also several reports about the detection of CTCs in patients with primary breast cancer, however, mostly with lower frequencies and varying results concerning both the number of positive patients as well as the number of CTCs in individual patients $[47,50,51$, $56-58]$.

\section{Phenotypical and Molecular Characterization of DTCs in Bone Marrow and CTCs in Blood}

The characterization of DTCs/CTCs is aimed to (1) provide evidence for their malignant origin and (2) identify further diagnostically and therapeutically relevant features of these cells, which might enable a more targeted and individualized antimetastatic therapy. This characterization is hampered by the fact that DTCs/CTCs can exhibit features distinct from the primary tumors, but on

Pathobiology 2008;75:140-148 
the other side this could help to identify cancer patients for additional targeted therapies.

By multiple fluorescence in situ hybridization analysis, Fehm et al. [59] could show that the vast majority of CTCs in blood from breast cancer patients are aneusomic and derived from the primary tumor. By single cell comparative genomic hybridization, Klein et al. [60] indicated that DTCs might be genomically unstable and heterogeneous. Moreover, Schmidt-Kittler et al. [61] suggested that DTCs from BM of breast cancer patients disseminate in a less progressed genomic state and might acquire genomic alterations typical for metastatic cells later.

The vast majority of DTCs in BM and CTCs in blood appear to persist in a nonproliferating state which was shown by Ki-67 negativity [10, 47]. Furthermore, only half of the breast cancer patients with DTCs relapse, whereas the other half remains tumor free over a 10-year follow-up period [19]. On the other side, this dormant state of DTCs/CTCs might also be the cause for the lack of effect of adjuvant chemotherapy on the elimination of these cells in high-risk breast cancer patients [18]. In order to escape from the dormant state into the dynamic phase of metastasis formation, dormancy has to be disturbed probably by both genetic and epigenetic changes in the DTCs/CTCs as well as in the surrounding microenvironment or premetastatic niche [14, 62, 63]. However, conditions and timing of outgrowth of dormant tumor cells are not known thus far $[1,13]$. Although there is evidence for a molecular signature of primary tumors spreading early into BM [64], there is only limited information about global gene expression analyses of DTCs/ CTCs. Transcriptional analyses of EpCAM-enriched BM and blood cells resulted in gene expression profiles that may be used to distinguish normal donors from cancer patients $[65,66]$. Further studies have to elucidate whether individual genes, the expression of which is changed in these cell populations, might become markers to recognize recurrence in breast cancer patients early [66]. Interestingly, TWIST1, a transcription factor that previously has been identified to play an important role in metastasis by promoting epithelial-mesenchymal transition [6770], was part of the gene expression signature identified in EpCAM-enriched cells from BM of breast cancer patients after chemotherapy [66]. TWIST1 expression, which was not observed in EpCAM-enriched cells of BM from healthy volunteers, correlated with the occurrence of distant metastasis and local progression, even in pretreatment BM samples [66].
DTCs/CTCs seem to be heterogeneous with regard to the expression of growth factor receptors, adhesion molecules, proteases and their inducers and receptors, major histocompatibility complex antigens or signaling kinases $[11,71-76]$. Of particular interest is the epidermal growth factor receptor HER2, the expression of which in primary tumors forms the basis of Herceptin treatment decisions for breast cancer patients. As shown by Braun et al. [77], HER2 overexpression on DTCs in BM was predictive for a poor clinical outcome of stage I-III breast cancer patients. While Vincent-Salomon et al. [78] showed on 27 breast cancer patients that the HER 2 status remained relatively stable between primary tumors and $\mathrm{BM}$ micrometastases in most cases, there is also increasing evidence for discrepancies between the HER2 status in primary tumors and DTCs in BM [79]. Solomayer et al. [79] detected HER2-positive DTCs in 12/20 BM samples from patients with HER2-negative primary tumors. Although HER2 expression was heterogeneous in DTCs from individual patients, HER2-positive DTCs might identify additional patients who can benefit from Herceptin therapy. The HER2 status of CTCs from PB might also be different from that of the corresponding primary tumors as reported by Wulfing et al. [80]. These authors presented a significant number of patients whose primary tumors were HER2 negative, whereas CTCs were HER2 positive before surgery [80]. Moreover, in this study the detection of HER2-positive CTCs correlated significantly with disease-free and overall survival [80]. It remains to be investigated whether high levels of HER2-positive CTCs reflect the activity of the tumor and have predictive value for an improved response of the patients to Herceptin treatment [80]. Although Meng et al. [81] reported a high agreement (97\%) of the HER2 status between primary tumors and CTCs in 31 cases, during tumor progression HER2-positive CTCs could be detected in 9 of 24 breast cancer patients in spite of HER2-negative primary tumors. These CTCs might have acquired HER2 gene amplifications. Four of these patients received Herceptin therapy and 3 of them responded to this therapy [81]. In the study reported by Apostolaki et al. [82], adjuvant chemotherapy eliminated HER 2 mRNA-positive CTCs in 16/45 patients. The detection of HER 2 mRNA-positive CTCs after chemotherapy was associated with a reduced disease-free survival. Moreover, in 8/161 patients with HER2-negative primary tumors, HER 2 mRNA-positive CTCs could be detected [82]. Thus, the detection of HER2 mRNA-positive CTCs after adjuvant chemotherapy in the PB of stage I and II breast cancer patients might provide information 
about the efficacy of chemotherapy and the prognosis of the patients and identify patients in need of additional Herceptin therapy [82].

\section{Detection of Stem Cell-Like Phenotypes}

The hypothesis that breast cancer might be originated from tissue stem or progenitor cells exhibiting the capability to self-renew and differentiate has gained increased attention during the last years [83-86]. Among the various features described for breast cancer stem cells, CD44 positivity and absence or weak expression of CD24 seem to be characteristic for breast cancer founder cells with a higher capacity to form tumors in immunosuppressed mice than other subtypes of breast cancer cells [87-89]. There is also evidence for CD133-positive stem cells in breast cancer $[90,91]$. Gene expression analysis of CD $44^{+} /$ CD24 $4^{- \text {low }}$ cells separated from CD44-negative cells of breast cancer tissue resulted in a 186-gene invasiveness gene signature which was significantly associated with overall and metastasis-free survival of breast cancer patients [92]. Furthermore, CD $44^{+} / \mathrm{CD} 24^{-/ \text {low }}$ breast cancer cells have upregulated different genes including Notch [93]. Very recently, Farnie et al. [94] demonstrated that aberrant activation of Notch signaling is an early event of breast cancer development. Apart from the Notch signaling pathway, other developmental pathways such as Wnt and hedgehog have been described to play a role in regulating cancer stem cell features $[95,96]$.

There are first hints that DTCs in BM also express stem cell features, as the majority of them are $\mathrm{CD} 44^{+} /$ $\mathrm{CD} 24^{-/ \text {low }}$ [97]. With a novel technique for the detection and characterization of secreted proteins from viable tumor cells, the EPISPOT assay, it was recently shown that both BM from metastatic and primary breast cancer patients contain DTCs with a breast cancer stem cell-like phenotype [41] characterized by cytokeratin 19 positivity and absence of Muc-1 secretion [98]. Further, recently described characteristics of DTCs are also consistent with their putative stem cell phenotype. Thus, most DTCs are in a nonproliferative state that renders them resistant to systemic chemotherapy and allows long-term persistence [18]. Abrogation of tumor cell dormancy in DTCs, the presence of which has prognostic relevance [19], by genetic aberrations or changes in the microenvironment might contribute to metastatic relapse.

\section{Conclusion}

Detection of DTCs/CTCs according to standardized protocols and subsequent comprehensive phenotypical and molecular characterization of these cells might contribute to an improved identification of patients in need of additional systemic anticancer therapy, to the stratification of patients to adjuvant therapies (for example Herceptin) and finally to the development of more tailored and personalized therapies for breast cancer patients. However, only prospective trials will show whether individual DTCs and CTCs are representative for the behavior of the entire pool of occult tumor cells and drug sensitivities of the corresponding cancer tissue. Furthermore, the impact of DTCs/CTCs as surrogate marker to monitor therapeutic interventions remains to be elucidated in future studies.

\section{References}

1 Pantel K, Brakenhoff RH: Dissecting the metastatic cascade. Nat Rev Cancer 2004;4: 448-456.

2 Paget S: The distribution of secondary growths in cancer of the breast. Lancet 1889; 1:571-573.

3 Rohr K, Hegglin R: Tumorzellen im Sternalpunktat. Dtsch Arch Klin Med 1936;179:6179.

4 Schreiber D: Demonstration of micrometastases in the bone marrow of clinically undiagnosed primary tumor. Z Arztl Fortbild (Jena) 1954;48:389-392.
5 Frey U, Senn HJ: Demonstration of osseous tumor micrometastases: comparison of the value of bone marrow cytology and histology. Schweiz Med Wochenschr 1978;108:8291.

6 Bauer K: Das Krebsproblem. Berlin, Springer, 1946.

-7 Sloane JP, Ormerod MG, Neville AM: Potential pathological application of immunocytochemical methods to the detection of micrometastases. Cancer Res 1980;40: 3079-3082.

8 Pantel K, Cote RJ, Fodstad O: Detection and clinical importance of micrometastatic disease. J Natl Cancer Inst 1999;91:1113-1124.
9 Pantel K, Woelfle U: Micrometastasis in breast cancer and other solid tumors. J Biol Regul Homeost Agents 2004;18:120-125.

10 Pantel K, Schlimok G, Braun S, Kutter D, Lindemann F, Schaller G, Funke I, Izbicki JR, Riethmuller G: Differential expression of proliferation-associated molecules in individual micrometastatic carcinoma cells. J Natl Cancer Inst 1993;85:1419-1424.

11 Pantel K, Schlimok G, Kutter D, Schaller G, Genz T, Wiebecke B, Backmann R, Funke I, Riethmuller G: Frequent down-regulation of major histocompatibility class I antigen expression on individual micrometastatic carcinoma cells. Cancer Res 1991;51:47124715 . 
-12 Allan AL, Vantyghem SA, Tuck AB, Chambers AF: Tumor dormancy and cancer stem cells: implications for the biology and treatment of breast cancer metastasis. Breast Dis 2006;26:87-98.

13 Alix-Panabieres C, Muller V, Pantel K: Current status in human breast cancer micrometastasis. Curr Opin Oncol 2007;19:558-563.

14 Vessella RL, Pantel K, Mohla S: Tumor cell dormancy: an NCI workshop report. Cancer Biol Ther 2007;6:1-9.

15 Lacroix M: Significance, detection and markers of disseminated breast cancer cells. Endocr Relat Cancer 2006;13:1033-1067.

16 Wolfle U, Muller V, Pantel K: Disseminated tumor cells in breast cancer: detection, characterization and clinical relevance. Future Oncol 2006;2:553-561.

-17 Pantel K, Schlimok G, Angstwurm M, Weckermann D, Schmaus W, Gath H, Passlick B, Izbicki JR, Riethmuller G: Methodological analysis of immunocytochemical screening for disseminated epithelial tumor cells in bone marrow. J Hematother 1994;3:165173.

-18 Braun S, Kentenich C, Janni W, Hepp F, de Waal J, Willgeroth F, Sommer H, Pantel K: Lack of effect of adjuvant chemotherapy on the elimination of single dormant tumor cells in bone marrow of high-risk breast cancer patients. J Clin Oncol 2000;18:80-86.

19 Braun S, Vogl FD, Naume B, Janni W, Osborne MP, Coombes RC, Schlimok G, Diel IJ, Gerber B, Gebauer G, Pierga JY, Marth C, Oruzio D, Wiedswang G, Solomayer EF, Kundt G, Strobl B, Fehm T, Wong GY, Bliss J, Vincent-Salomon A, Pantel K: A pooled analysis of bone marrow micrometastasis in breast cancer. N Engl J Med 2005;353:793-802.

-20 Janni W, Rack B, Schindlbeck C, Strobl B, Rjosk D, Braun S, Sommer H, Pantel K, Gerber B, Friese K: The persistence of isolated tumor cells in bone marrow from patients with breast carcinoma predicts an increased risk for recurrence. Cancer 2005;103:884891.

-21 Fetsch PA, Cowan KH, Weng DE, Freifield A, Filie AC, Abati A: Detection of circulating tumor cells and micrometastases in stage II, III, and IV breast cancer patients utilizing cytology and immunocytochemistry. Diagn Cytopathol 2000;22:323-328.

-22 Slade MJ, Singh A, Smith BM, Tripuraneni G, Hall E, Peckitt C, Fox S, Graham H, Luchtenborg M, Sinnett HD, Cross NC, Coombes RC: Persistence of bone marrow micrometastases in patients receiving adjuvant therapy for breast cancer: results at 4 years. Int J Cancer 2005;114:94-100.

-23 Fehm T, Braun S, Muller V, Janni W, Gebauer G, Marth C, Schindlbeck C, Wallwiener D, Borgen E, Naume B, Pantel K, Solomayer E: A concept for the standardized detection of disseminated tumor cells in bone marrow from patients with primary breast cancer and its clinical implementation. Cancer 2006;107:885-892.
24 Borgen E, Beiske K, Trachsel S, Nesland JM, Kvalheim G, Herstad TK, Schlichting E, Qvist $H$, Naume B: Immunocytochemical detection of isolated epithelial cells in bone marrow: non-specific staining and contribution by plasma cells directly reactive to alkaline phosphatase. J Pathol 1998;185:427434.

25 Borgen E, Naume B, Nesland JM, Nowels KW, Pavlak N, Ravkin I, Goldbard S: Use of automated microscopy for the detection of disseminated tumor cells in bone marrow samples. Cytometry 2001;46:215-221.

26 Borgen E, Pantel K, Schlimok G, Muller P, Otte M, Renolen A, Ehnle S, Coith C, Nesland JM, Naume B: A European interlaboratory testing of three well-known procedures for immunocytochemical detection of epithelial cells in bone marrow: results from analysis of normal bone marrow. Cytometry B Clin Cytom 2006;70:400-409.

27 Muller HM, Widschwendter A, Fiegl H, Ivarsson L, Goebel G, Perkmann E, Marth C, Widschwendter M: DNA methylation in serum of breast cancer patients: an independent prognostic marker. Cancer Res 2003;63: 7641-7645.

28 Schwarzenbach H, Muller V, Beeger C, Gottberg M, Stahmann N, Pantel K: A critical evaluation of loss of heterozygosity detected in tumor tissues, blood serum and bone marrow plasma from patients with breast cancer. Breast Cancer Res 2007;9:R66.

29 Ring A, Smith IE, Dowsett M: Circulating tumour cells in breast cancer. Lancet Oncol 2004;5:79-88.

30 Schoenfeld A, Kruger KH, Gomm J, Sinnett HD, Gazet JC, Sacks N, Bender HG, Luqmani Y, Coombes RC: The detection of micrometastases in the peripheral blood and bone marrow of patients with breast cancer using immunohistochemistry and reverse transcriptase polymerase chain reaction for keratin 19. Eur J Cancer 1997;33:854-861.

31 Smith BM, Slade MJ, English J, Graham H, Luchtenborg M, Sinnett HD, Cross NC, Coombes RC: Response of circulating tumor cells to systemic therapy in patients with metastatic breast cancer: comparison of quantitative polymerase chain reaction and immunocytochemical techniques. J Clin Oncol 2000;18:1432-1439.

- 32 Berois N, Varangot M, Aizen B, Estrugo R, Zarantonelli L, Fernandez P, Krygier G, Simonet F, Barrios E, Muse I, Osinaga E: Molecular detection of cancer cells in bone marrow and peripheral blood of patients with operable breast cancer: comparison of CK19, MUC1 and CEA using RT-PCR. Eur J Cancer 2000;36:717-723.
3 Zhong XY, Kaul S, Lin YS, Eichler A, Bastert G: Sensitive detection of micrometastases in bone marrow from patients with breast cancer using immunomagnetic isolation of tumor cells in combination with reverse transcriptase/polymerase chain reaction for cytokeratin-19. J Cancer Res Clin Oncol 2000;126:212-218.

34 Bossolasco P, Ricci C, Farina G, Soligo D, Pedretti D, Scanni A, Deliliers GL: Detection of micrometastatic cells in breast cancer by RT$\mathrm{pCR}$ for the mammaglobin gene. Cancer Detect Prev 2002;26:60-63.

35 Becker S, Becker-Pergola G, Fehm T, Wallwiener D, Solomayer EF: Time is an important factor when processing samples for the detection of disseminated tumor cells in blood/bone marrow by reverse transcription-PCR. Clin Chem 2004;50:785-786.

- 36 Ballestrero A, Garuti A, Bertolotto M, Rocco I, Boy D, Nencioni A, Ottonello L, Patrone F: Effect of different cytokines on mammaglobin and maspin gene expression in normal leukocytes: possible relevance to the assays for the detection of micrometastatic breast cancer. Br J Cancer 2005;92:1948-1952.

- 37 Ring AE, Zabaglo L, Ormerod MG, Smith IE, Dowsett M: Detection of circulating epithelial cells in the blood of patients with breast cancer: comparison of three techniques. Br J Cancer 2005;92:906-912.

38 Balducci E, Azzarello G, Valori L, Toffolatti L, Bolgan L, Valenti MT, Bari M, Pappagallo GL, Ausoni S, Vinante O: A new nested primer pair improves the specificity of CK19 mRNA detection by RT-PCR in occult breast cancer cells. Int J Biol Markers 2005; 20:28-33.

39 Benoy IH, Elst H, Philips M, Wuyts H, Van Dam P, Scharpe S, Van Marck E, Vermeulen PB, Dirix LY: Prognostic significance of disseminated tumor cells as detected by quantitative real-time reverse-transcriptase polymerase chain reaction in patients with breast cancer. Clin Breast Cancer 2006;7:146-152.

40 Zach O, Lutz D: Tumor cell detection in peripheral blood and bone marrow. Curr Opin Oncol 2006;18:48-56.

41 Alix-Panabieres C, Vendrell JP, Pelle O, Rebillard X, Riethdorf S, Muller V, Fabbro M, Pantel K: Detection and characterization of putative metastatic precursor cells in cancer patients. Clin Chem 2007;53:537-539.

-42 Pantel K, Felber E, Schlimok G: Detection and characterization of residual disease in breast cancer. J Hematother 1994;3:315322.

43 Braun S, Pantel K, Muller P, Janni W, Hepp F, Kentenich CR, Gastroph S, Wischnik A, Dimpfl T, Kindermann G, Riethmuller G, Schlimok G: Cytokeratin-positive cells in the bone marrow and survival of patients with stage I, II, or III breast cancer. N Engl J Med 2000;342:525-533. 
44 Gebauer G, Fehm T, Merkle E, Beck EP, Lang $\mathrm{N}$, Jager W: Epithelial cells in bone marrow of breast cancer patients at time of primary surgery: clinical outcome during long-term follow-up. J Clin Oncol 2001;19:3669-3674.

-45 Wiedswang G, Borgen E, Karesen R, Qvist H, Janbu J, Kvalheim G, Nesland JM, Naume B: Isolated tumor cells in bone marrow three years after diagnosis in disease-free breast cancer patients predict unfavorable clinical outcome. Clin Cancer Res 2004;10:53425348.

-46 Pierga JY, Bonneton C, Vincent-Salomon A, de Cremoux P, Nos C, Blin N, Pouillart P, Thiery JP, Magdelenat H: Clinical significance of immunocytochemical detection of tumor cells using digital microscopy in peripheral blood and bone marrow of breast cancer patients. Clin Cancer Res 2004;10: 1392-1400.

-47 Muller V, Stahmann N, Riethdorf S, Rau T, Zabel T, Goetz A, Janicke F, Pantel K: Circulating tumor cells in breast cancer: correlation to bone marrow micrometastases, heterogeneous response to systemic therapy and low proliferative activity. Clin Cancer Res 2005;11:3678-3685.

48 Wiedswang G, Borgen E, Schirmer C, Karesen R, Kvalheim G, Nesland JM, Naume B: Comparison of the clinical significance of occult tumor cells in blood and bone marrow in breast cancer. Int J Cancer 2006;118:20132019.

49 Benoy IH, Elst H, Philips M, Wuyts H, Van Dam P, Scharpe S, Van Marck E, Vermeulen PB, Dirix LY: Real-time RT-PCR detection of disseminated tumour cells in bone marrow has superior prognostic significance in comparison with circulating tumour cells in patients with breast cancer. Br J Cancer 2006; 94:672-680.

50 Xenidis N, Perraki M, Kafousi M, Apostolaki S, Bolonaki I, Stathopoulou A, Kalbakis K, Androulakis N, Kouroussis C, Pallis T, Christophylakis C, Argyraki K, Lianidou ES, Stathopoulos S, Georgoulias V, Mavroudis $\mathrm{D}$ : Predictive and prognostic value of peripheral blood cytokeratin-19 mRNA-positive cells detected by real-time polymerase chain reaction in node-negative breast cancer patients. J Clin Oncol 2006;24:3756-3762.

-51 Nakagawa T, Martinez SR, Goto Y, Koyanagi K, Kitago M, Shingai T, Elashoff DA, Ye X, Singer FR, Giuliano AE, Hoon DS: Detection of circulating tumor cells in early-stage breast cancer metastasis to axillary lymph nodes. Clin Cancer Res 2007;13:4105-4110.

- 52 Cristofanilli M, Budd GT, Ellis MJ, Stopeck A, Matera J, Miller MC, Reuben JM, Doyle GV, Allard WJ, Terstappen LW, Hayes DF: Circulating tumor cells, disease progression, and survival in metastatic breast cancer. $\mathrm{N}$ Engl J Med 2004;351:781-791.
53 Cristofanilli M, Hayes DF, Budd GT, Ellis MJ, Stopeck A, Reuben JM, Doyle GV, Matera J, Allard WJ, Miller MC, Fritsche HA, Hortobagyi GN, Terstappen LW: Circulating tumor cells: a novel prognostic factor for newly diagnosed metastatic breast cancer. J Clin Oncol 2005;23:1420-1430.

54 Hayes DF, Cristofanilli M, Budd GT, Ellis MJ, Stopeck A, Miller MC, Matera J, Allard WJ, Doyle GV, Terstappen LW: Circulating tumor cells at each follow-up time point during therapy of metastatic breast cancer patients predict progression-free and overall survival. Clin Cancer Res 2006;12:42184224.

55 Riethdorf S, Fritsche H, Muller V, Rau T, Schindlbeck C, Rack B, Janni W, Coith C, Beck K, Janicke F, Jackson S, Gornet T, Cristofanilli M, Pantel K: Detection of circulating tumor cells in peripheral blood of patients with metastatic breast cancer: a validation study of the CellSearch system. Clin Cancer Res 2007;13:920-928.

-56 Witzig TE, Bossy B, Kimlinger T, Roche PC, Ingle JN, Grant C, Donohue J, Suman VJ, Harrington D, Torre-Bueno J, Bauer KD: Detection of circulating cytokeratin-positive cells in the blood of breast cancer patients using immunomagnetic enrichment and digital microscopy. Clin Cancer Res 2002;8: 1085-1091.

57 Pachmann K, Camara O, Kavallaris A, Schneider U, Schunemann S, Hoffken K: Quantification of the response of circulating epithelial cells to neodadjuvant treatment for breast cancer: a new tool for therapy monitoring. Breast Cancer Res 2005;7:R975R979.

58 Kahn HJ, Presta A, Yang LY, Blondal J, Trudeau M, Lickley L, Holloway C, McCready DR, Maclean D, Marks A: Enumeration of circulating tumor cells in the blood of breast cancer patients after filtration enrichment: correlation with disease stage. Breast Cancer Res Treat 2004;86:237247.

59 Fehm T, Sagalowsky A, Clifford E, Beitsch P, Saboorian H, Euhus D, Meng S, Morrison L, Tucker T, Lane N, Ghadimi BM, Heselmeyer-Haddad K, Ried T, Rao C, Uhr J: Cytogenetic evidence that circulating epithelial cells in patients with carcinoma are malignant. Clin Cancer Res 2002;8:2073-2084.

60 Klein CA, Blankenstein TJ, Schmidt-Kittler O, Petronio M, Polzer B, Stoecklein NH, Riethmuller G: Genetic heterogeneity of single disseminated tumour cells in minimal residual cancer. Lancet 2002;360:683-689.

61 Schmidt-Kittler O, Ragg T, Daskalakis A, Granzow M, Ahr A, Blankenstein TJ, Kaufmann M, Diebold J, Arnholdt H, Muller P, Bischoff J, Harich D, Schlimok G, Riethmuller G, Eils R, Klein CA: From latent disseminated cells to overt metastasis: genetic analysis of systemic breast cancer progression. Proc Natl Acad Sci USA 2003;100: 7737-7742.
62 Naumov GN, Bender E, Zurakowski D, Kang SY, Sampson D, Flynn E, Watnick RS, Straume O, Akslen LA, Folkman J, Almog N: A model of human tumor dormancy: an angiogenic switch from the nonangiogenic phenotype. J Natl Cancer Inst 2006;98:316-325.

63 Marches R, Scheuermann R, Uhr J: Cancer dormancy: from mice to man. Cell Cycle 2006;5:1772-1778.

64 Woelfle U, Cloos J, Sauter G, Riethdorf L, Janicke F, van Diest P, Brakenhoff R, Pantel $\mathrm{K}$ : Molecular signature associated with bone marrow micrometastasis in human breast cancer. Cancer Res 2003;63:5679-5684.

65 Smirnov DA, Zweitzig DR, Foulk BW, Miller MC, Doyle GV, Pienta KJ, Meropol NJ, Weiner LM, Cohen SJ, Moreno JG, Connelly MC, Terstappen LW, O'Hara SM: Global gene expression profiling of circulating tumor cells. Cancer Res 2005;65:4993-4997.

66 Watson MA, Ylagan LR, Trinkaus KM, Gillanders WE, Naughton MJ, Weilbaecher KN, Fleming TP, Aft RL: Isolation and molecular profiling of bone marrow micrometastases identifies TWIST1 as a marker of early tumor relapse in breast cancer patients. Clin Cancer Res 2007;13:5001-5009.

67 Rosivatz E, Becker I, Specht K, Fricke E, Luber B, Busch R, Hofler H, Becker KF: Differential expression of the epithelial-mesenchymal transition regulators snail, SIP1, and twist in gastric cancer. Am J Pathol 2002; 161:1881-1891.

68 Kang Y, Massague J: Epithelial-mesenchymal transitions: twist in development and metastasis. Cell 2004;118:277-279.

69 Cheng GZ, Chan J, Wang Q, Zhang W, Sun CD, Wang LH: Twist transcriptionally upregulates AKT 2 in breast cancer cells leading to increased migration, invasion, and resistance to paclitaxel. Cancer Res 2007;67: 1979-1987.

70 Lo HW, Hsu SC, Xia W, Cao X, Shih JY, Wei Y, Abbruzzese JL, Hortobagyi GN, Hung MC: Epidermal growth factor receptor cooperates with signal transducer and activator of transcription 3 to induce epithelial-mesenchymal transition in cancer cells via up-regulation of TWIST gene expression. Cancer Res 2007;67:9066-9076.

71 Klein CA, Seidl S, Petat-Dutter K, Offner S, Geigl JB, Schmidt-Kittler O, Wendler N, Passlick B, Huber RM, Schlimok G, Baeuerle PA, Riethmuller G: Combined transcriptome and genome analysis of single micrometastatic cells. Nat Biotechnol 2002;20: 387-392.

72 Hemsen A, Riethdorf L, Brunner N, Berger J, Ebel S, Thomssen C, Janicke F, Pantel K: Comparative evaluation of urokinase-type plasminogen activator receptor expression in primary breast carcinomas and on metastatic tumor cells. Int J Cancer 2003;107: 903-909. 
-73 Thurm H, Ebel S, Kentenich C, Hemsen A, Riethdorf S, Coith C, Wallwiener D, Braun S, Oberhoff C, Janicke F, Pantel K: Rare expression of epithelial cell adhesion molecule on residual micrometastatic breast cancer cells after adjuvant chemotherapy. Clin Cancer Res 2003;9:2598-2604.

74 Reimers N, Zafrakas K, Assmann V, Egen C, Riethdorf L, Riethdorf S, Berger J, Ebel S, Janicke F, Sauter G, Pantel K: Expression of extracellular matrix metalloproteases inducer on micrometastatic and primary mammary carcinoma cells. Clin Cancer Res 2004;10:3422-3428

-75 Meng S, Tripathy D, Shete S, Ashfaq R, Saboorian H, Haley B, Frenkel E, Euhus D, Leitch M, Osborne C, Clifford E, Perkins S, Beitsch P, Khan A, Morrison L, Herlyn D, Terstappen LW, Lane N, Wang J, Uhr J: uPAR and HER-2 gene status in individual breast cancer cells from blood and tissues. Proc Natl Acad Sci USA 2006;103:17361-17365.

-76 Kallergi G, Mavroudis D, Georgoulias V, Stournaras C: Phosphorylation of FAK, PI$3 \mathrm{~K}$, and impaired actin organization in CKpositive micrometastatic breast cancer cells. Mol Med 2007;13:79-88.

-77 Braun S, Schlimok G, Heumos I, Schaller G, Riethdorf L, Riethmuller G, Pantel K: ErbB2 overexpression on occult metastatic cells in bone marrow predicts poor clinical outcome of stage I-III breast cancer patients. Cancer Res 2001;61:1890-1895.

-78 Vincent-Salomon A, Pierga JY, Couturier J, d'Enghien CD, Nos C, Sigal-Zafrani B, Lae M, Freneaux P, Dieras V, Thiery JP, SastreGarau X: HER2 status of bone marrow micrometastasis and their corresponding primary tumours in a pilot study of 27 cases: a possible tool for anti-HER2 therapy management? Br J Cancer 2007;96:654-659.

80 Wulfing P, Borchard J, Buerger H, Heidl S, Zanker KS, Kiesel L, Brandt B: HER2-positive circulating tumor cells indicate poor clinical outcome in stage I to III breast cancer patients. Clin Cancer Res 2006;12:17151720 .

81 Meng S, Tripathy D, Shete S, Ashfaq R, Haley B, Perkins S, Beitsch P, Khan A, Euhus D, Osborne C, Frenkel E, Hoover S, Leitch M, Clifford E, Vitetta E, Morrison L, Herlyn D, Terstappen LW, Fleming T, Fehm T, Tucker T, Lane N, Wang J, Uhr J: HER-2 gene amplification can be acquired as breast cancer progresses. Proc Natl Acad Sci USA 2004;101: 9393-9398.

82 Apostolaki S, Perraki M, Pallis A, Bozionelou V, Agelaki S, Kanellou P, Kotsakis A, Politaki E, Kalbakis K, Kalykaki A, Vamvakas L, Georgoulias V, Mavroudis D: Circulating HER2 mRNA-positive cells in the peripheral blood of patients with stage I and II breast cancer after the administration of adjuvant chemotherapy: evaluation of their clinical relevance. Ann Oncol 2007;18:851858.

83 Ponti D, Costa A, Zaffaroni N, Pratesi G, Petrangolini G, Coradini D, Pilotti S, Pierotti MA, Daidone MG: Isolation and in vitro propagation of tumorigenic breast cancer cells with stem/progenitor cell properties. Cancer Res 2005;65:5506-5511.

84 Ponti D, Zaffaroni N, Capelli C, Daidone MG: Breast cancer stem cells: an overview. Eur J Cancer 2006;42:1219-1224.

85 Wicha MS, Liu S, Dontu G: Cancer stem cells: an old idea - a paradigm shift. Cancer Res 2006;66:1883-1890; discussion 18951896.

86 Stingl J, Caldas C: Molecular heterogeneity of breast carcinomas and the cancer stem cell hypothesis. Nat Rev Cancer 2007;7:791-799.

79 Solomayer EF, Becker S, Pergola-Becker G, $>87$ Sheridan C, Kishimoto H, Fuchs RK, MehBachmann R, Kramer B, Vogel U, Neubauer $\mathrm{H}$, Wallwiener D, Huober J, Fehm TN: Comparison of HER2 status between primary tumor and disseminated tumor cells in primary breast cancer patients. Breast Cancer Res Treat 2006;98:179-184. rotra S, Bhat-Nakshatri P, Turner $\mathrm{CH}$, Goulet R Jr, Badve S, Nakshatri H: CD44+/CD24breast cancer cells exhibit enhanced invasive properties: an early step necessary for metastasis. Breast Cancer Res 2006;8:R59.

88 Phillips TM, McBride WH, Pajonk F: The response of CD24(-/low)/CD44+ breast cancer-initiating cells to radiation. J Natl Cancer Inst 2006;98:1777-1785.

89 Fillmore C, Kuperwasser C: Human breast cancer stem cell markers CD44 and CD24: enriching for cells with functional properties in mice or in man? Breast Cancer Res 2007;9:303.
90 Storci G, Sansone P, Trere D, Tavolari S, Taffurelli M, Ceccarelli C, Guarnieri T, Paterini P, Pariali M, Montanaro L, Santini D, Chieco P, Bonafe M: The basal-like breast carcinoma phenotype is regulated by SLUG gene expression. J Pathol 2008;214:25-37.

91 Zucchi I, Sanzone S, Astigiano S, Pelucchi P, Scotti M, Valsecchi V, Barbieri O, Bertoli G, Albertini A, Reinbold RA, Dulbecco R: The properties of a mammary gland cancer stem cell. Proc Natl Acad Sci USA 2007;104: 10476-10481.

92 Liu R, Wang X, Chen GY, Dalerba P, Gurney A, Hoey T, Sherlock G, Lewicki J, Shedden K, Clarke MF: The prognostic role of a gene signature from tumorigenic breast-cancer cells. N Engl J Med 2007;356:217-226.

93 Farnie G, Clarke RB: Mammary stem cells and breast cancer-role of notch signalling. Stem Cell Rev 2007;3:169-175.

94 Farnie G, Clarke RB, Spence K, Pinnock N, Brennan K, Anderson NG, Bundred NJ: Novel cell culture technique for primary ductal carcinoma in situ: role of Notch and epidermal growth factor receptor signaling pathways. J Natl Cancer Inst 2007;99:616627.

95 Liu S, Dontu G, Mantle ID, Patel S, Ahn NS, Jackson KW, Suri P, Wicha MS: Hedgehog signaling and Bmi-1 regulate self-renewal of normal and malignant human mammary stem cells. Cancer Res 2006;66:6063-6071.

96 Lindvall C, Bu W, Williams BO, Li Y: Wnt signaling, stem cells, and the cellular origin of breast cancer. Stem Cell Rev 2007;3:157168 .

$\$ 97$ Balic M, Lin H, Young L, Hawes D, Giuliano A, McNamara G, Datar RH, Cote RJ: Most early disseminated cancer cells detected in bone marrow of breast cancer patients have a putative breast cancer stem cell phenotype. Clin Cancer Res 2006;12:5615-5621.

98 Gudjonsson T, Villadsen R, Nielsen HL, Ronnov-Jessen L, Bissell MJ, Petersen OW: Isolation, immortalization, and characterization of a human breast epithelial cell line with stem cell properties. Genes Dev 2002; 16:693-706. 